\title{
Upaya Peningkatan Pemahaman Kewajiban Perpajakan Pada Pelaku Industri Kecil dan Menengah (IKM) Kota Tegal
}

\author{
Ida Farida ${ }^{1}$, Sunandar ${ }^{2}$, Yeni Priatna Sari ${ }^{3}$ \\ Program Studi D3 Akuntansi, Politeknik Harapan Bersama \\ Email : faridah90@gmail.com
}

\begin{abstract}
Abstrak
Industri Kecil dan Menengah (IKM) tidak akan pernah lepas dari istilah perpajakan. Mengingat pentingnya pajak bagi Negara Indonesia maka diupayakan agar masyarakat Indonesia khususnya para pelaku Industri Kecil dan Menengah (IKM) di Kota Tegal semakin banyak yang memahami tentang pajak khususnya Pajak Penghasilan (PPh) orang pribadi. Pelatihan pengisian SPT pajak PPh orang pribadi merupakan salah satu upaya yang dilakukan agar para pelaku Industri Kecil dan Menengah (IKM) semakin mengerti akan pentingnya pemenuhan kewajiban perpajakan karena Undang-undang (UU) perpajakan di Indonesia terus mengalami perubahan. perhitungan Pajak Penghasilan (PPh) baik wajib pajak badan maupun wajib pajak pribadi mulai tahun 2009 harus mengacu pada UU PPh baru. Wajib pajak yang tidak ber-NPWP akan dikenakan wajib pajak yang lebih tinggi. Perubahan ini pasti akan berdampak pada masyarakat dengan semakin banyaknya warga Negara yang ber-NPWP. Dengan adanya pelatihan ini diharapkan peserta mampu memahami pokok-pokok perubahan dari UU perpajakan yang baru.
\end{abstract}

Kata Kunci : IKM, SPT PPh Orang Pribadi, NPWP, Perpajakan.

\section{PENDAHULUAN}

Pajak adalah salah satu isu yang menjadi perhatian masyarakat Indonesia beberapa tahun belakangan ini. Pajak menurut Mardiasmo adalah iuran rakyat kepada kas negara berdasarkan Undang-Undang yang dapat dipaksakan dengan tidak mendapat jasa timbal balik yang langsung dapat ditunjukkan dan yang digunakan untuk membayar pengeluaran umum ${ }^{[1]}$. Di Indonesia pajak merupakan salah satu sumber utama penerimaan Negara selain dari sektor migas dan non migas untuk membiayai pembangunan sarana umum, pertahanan dan keamanan, serta dana pemilu. Pajak juga digunakan untuk mensubsidi barang-barang yang sangat dibutuhkan masyarakat seperti subsidi bahan pangan dan Bahan Bakar Minyak (BBM). Melihat pentingnya pajak menyebabkan banyak masyarakat yang tertarik dengan isu pajak. Ketertarikan masyarakat terhadap perpajakan terbukti dengan banyaknya pemberitaan tentang pajak baik media elektronik maupun cetak yang menambah pengetahuan masyarakat tentang pajak.

Industri Kecil dan Menengah (IKM) memiliki peran yang penting dalam mendorong pertumbuhan ekonomi secara menyeluruh. Peran Industri Kecil dan Menengah (IKM) dirasakan sangat penting terutama dalam aspek-aspek seperti kesempatan kerja, pemerataan pendapatan, dan pembangunan ekonomi masyarakat. Kota Tegal yang pernah disebut sebagai Jepangnya Indonesia, memiliki jumlah IKM (Industri Kecil Menengah) sebanyak 1.661 IKM besar dan kecil yang tersebar di 4 (empat) wilayah Kecamatan dan berbagai produksi mulai dari industri logam, kuliner, konveksi, kerajinan tangan, alat olah raga, alat transportasi, fashion dan masih banyak lagi dan menyerap 5397 tenaga kerja. (http://sim-ikm.tegalkota.go.id) ${ }^{[2]}$.

Kedudukan Industri Kecil dan Menengah (IKM) di Kota Tegal tidak akan pernah lepas dari istilah perpajakan. Industri Kecil dan Menengah (IKM) menurut Surat Edaran Bank Indonesia (dalam Ratnasari, 2013) ${ }^{[3]}$, industri kecil adalah suatu usaha dalam bentuk 
industri yang dijalankan oleh rakyat miskin atau mendekati miskin, yang memiliki aset $<\mathrm{Rp}$ 200 juta atau omset Rp 1 milyar, bersifat industri keluarga, menggunakan sumber daya lokal, menerapkan teknologi sederhana dan mudah keluar masuk industri. Kemudian industri menengah adalah industri yang sedikit lebih besar dari industri kecil, industri menengah merupakan industri kecil yang berkembang sehingga memiliki aset $<\mathrm{Rp} 5$ milyar untuk kegiatan industri, aset $<$ Rp 600 juta untuk kegiatan lainnya. Mengingat pentingnya pajak bagi bagi para pelaku Industri Kecil dan Menengah (IKM) di Negara Indonesia maka diupayakan agar masyarakat Indonesia khususnya para pelaku Industri Kecil dan Menengah (IKM) di Kota Tegal semakin banyak yang memahami dan mengetahui tentang pajak khususnya SPT $\mathrm{PPh}$ orang pribadi karena di Industri Kecil dan menengah banyak yang memperkerjakan karyawan yang terampil sebagai pegawainya.

Pelatihan pengisian SPT PPh Wajib Pajak orang pribadi merupakan salah satu upaya yang dilakukan agar para pelaku Industri Kecil dan Menengah (IKM) semakin mengerti untuk memenuhi kewajiban perpajakan karena Undang-undang (UU) perpajakan di Indonesia terus mengalami perubahan. Pengertian mengisi SPT menurut Waluyo yaitu mengisi formulir SPT dalam bentuk kertas dan/atau dalam bentuk elektronik, dengan benar, lengkap, jelas sesuai dengan petunjuk pengisian yang diberikan berdasarkan ketetuan peraturan perundang-undangan perpajakan ${ }^{[4]}$. Perhitungan Pajak Penghasilan $(\mathrm{PPh})$ baik wajib pajak badan maupun wajib pajak pribadi mulai tahun 2009 harus mengacu pada Undang-Undang PPh baru. Wajib pajak yang tidak ber-NPWP akan dikenakan wajib pajak yang lebih tinggi. Perubahan ini pasti akan berdampak pada masyarakat dengan semakin banyaknya warga negara yang ber-NPWP. Dengan adanya pelatihan ini diharapkan peserta mampu memahami pokok-pokok perubahan dari Undang-Undang (UU) perpajakan yang baru untuk Industri Kecil dan Menengah (IKM) di Kota Tegal.

\section{METODE}

Adapun langkah-langkah pemecahan masalah atau metode pelaksanaan kegiatan upaya peningkatan pemahaman kewajiban perpajakan pada pelaku Industri Kecil dan Menengah (IKM) Kota Tegal adalah sebagai berikut:

\subsection{Pemetaan (mapping)}

Pemetaan dilakukan pada saat menganalisis situasi dengan memetakan permasalahan apa yang dihadapi dan solusi apa yang dibutuhkan. Dari hasil pemetaan yang dibutuhkan oleh para pelaku Industri Kecil dan Menengah (IKM) adalah pengetahuan tentang perkembangan perpajakan dan praktek pengisian SPT PPh WP Orang Pribadi secara lebih rinci.

2.2 Wawancara dengan para pelaku Industri Kecil dan Menengah (IKM)

Wawancara juga dilakukan kepada beberapa para pelaku tentang apa saja yang telah dipelajari dan dipahami agar memiliki gambaran materi apa saja yang dibutuhkan oleh para pelaku Industri Kecil dan Menengah (IKM) untuk menambah pengetahuan tentang pajak.

2.2 Perumusan masalah dan Solusi

Perumusan masalah dilakukan dengan tujuan mencari solusi yang dapat dilakukan.

Perumusan masalah dalam pengabdian pada masyarakat ini adalah :

2.2.1 Bagaimana pentingnya pajak bagi IKM ?

2.2.2 Apakah yang dimaksud PPh Orang Pribadi ?

2.2.3 Bagaimana pengisian SPT Tahunan WP Orang Pribadi?

2.2.4 Bagaimana cara menyampaikan / melaporkan SPT PPh WP Orang Pribadi ?

Solusi yang dilakukan dengan cara memberikan pelatihan berkaitan dengan pemahaman mengenai pajak bagi IKM , cara mengisi SPT Tahunan PPh WP Orang Pribadi dan 
cara melaporkan SPT Tahunan PPh WP Orang Pribadi ke Kantor Pelayanan Pajak (KPP) Pratama Kota Tegal.

2.3 Metode penyelesaian masalah

Metode penyelesaian masalah dalam kegiatan pengabdian masyarakat ini adalah dengan melakukan pelatihan untuk menambah wawasan bagi para pelaku Industri Kecil dan Menengah (IKM) di Kota Tegal tentang pajak, serta menumbuhkan kesadaran pada para pelaku Industri Kecil dan Menengah (IKM) tentang pentingnya pajak bagi Negara Indonesia.

2.4 Tahap implementasi dan pelaksanaan

Pelaksanaan Pengabdian Kepada Masyarakat ini dilakukan dengan menggunakan metode ceramah, tutorial dan diskusi. Adapun sistematika pelaksanaan kegiatan pengabdian adalah sebagai berikut:

2.4.1 Metode Ceramah

Peserta diberikan motivasi agar memiliki pemahaman tetang pajak dan pentingnya pajak bagi IKM. Peserta juga diberikan gambaran umum tentang perubahan-perubahan peraturan perpajakan di Indonesia khususnya $\mathrm{PPh}$ orang pribadi. Selain itu peserta juga diberikan gambaran umum keterkaitan IKM dengan pajak.

\subsubsection{Metode Tutorial}

Peserta pelatihan diberikan materi dan praktek pengisian SPT PPh WP orang pribadi. Peserta pelatihan dipandu untuk mengisi formulir SPT PPh WP orang pribadi.

2.4.3 Metode Diskusi

Peserta pelatihan diberikan kesempatan untuk mendiskusikan permasalahan yang berkaitan dengan pajak dan cara pengisian SPT PPhWP orang pribadi.

\subsection{Kegiatan Pelatihan}

\section{HASIL DAN PEMBAHASAN}

Sebagai upaya dalam peningkatan pemahaman para pelaku Industri Kecil dan Menengah (IKM) tentang pentingnya pajak bagi Industri Kecil dan Menengah (IKM) di Kota Tegal. Peserta kegiatan diberikan berbagai macam materi diantaranya adalah sebagai berikut :

\section{Mengenal Pajak bagi IKM}

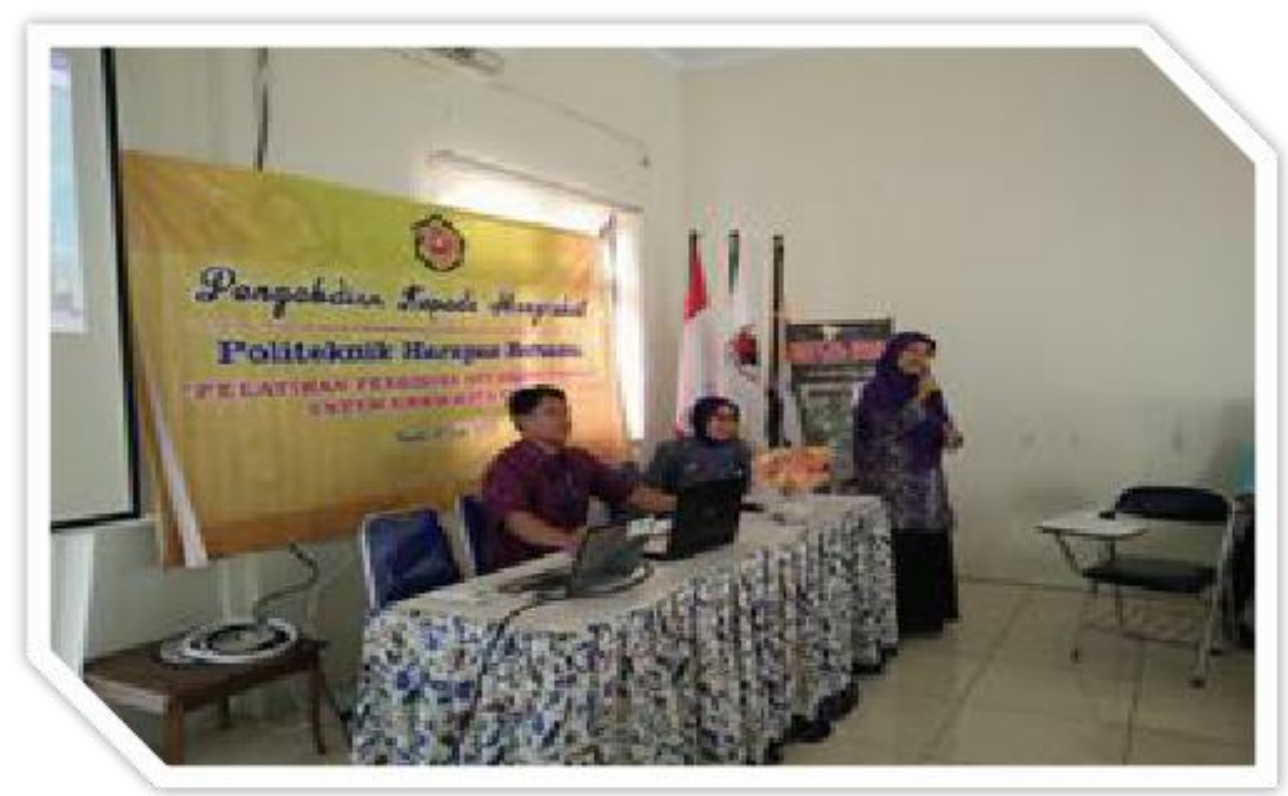

Gambar 1. Pemberian Materi Pajak bagi IKM 


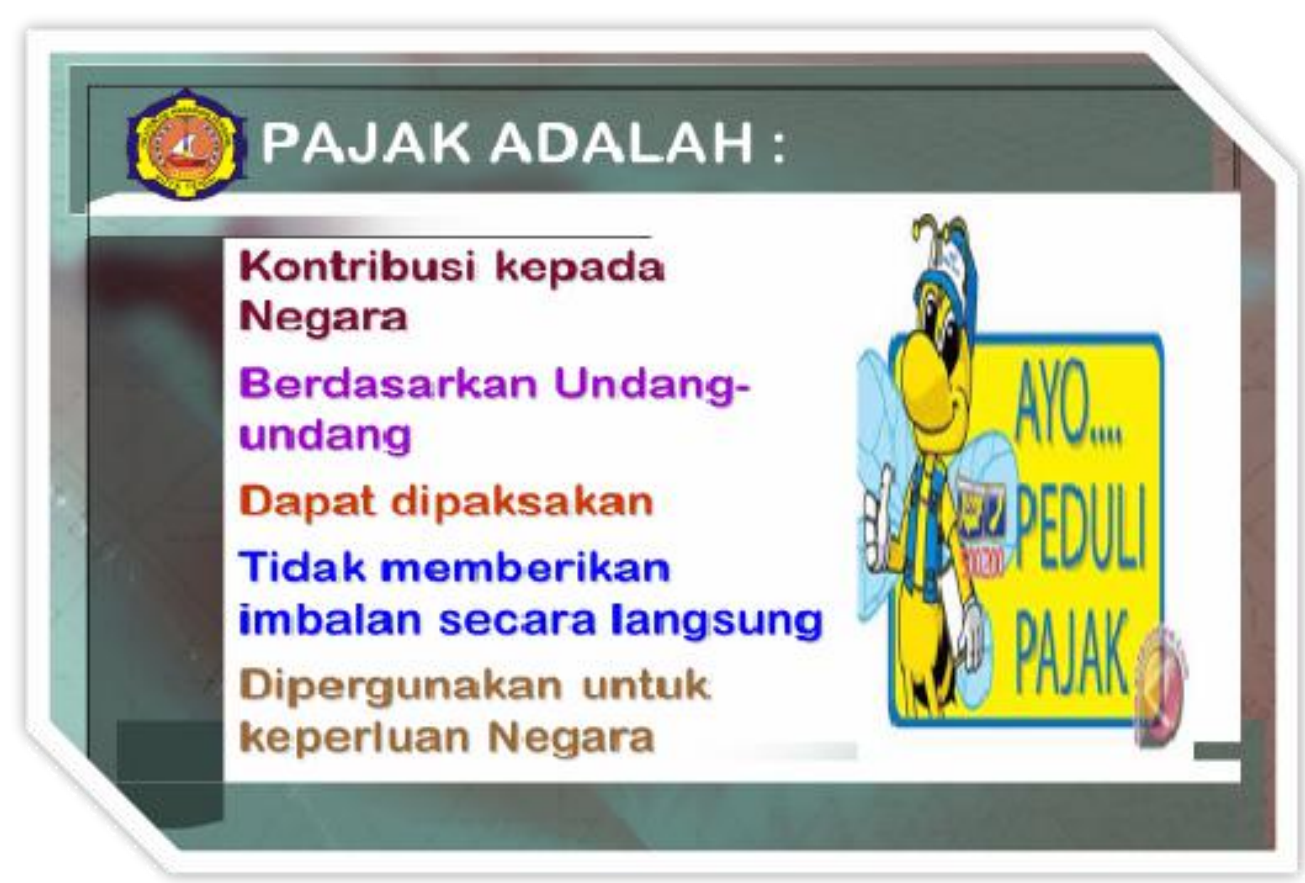

Gambar 2. Materi Pengenalan Pajak bagi IKM.

2. $\quad$ PPh Orang Pribadi

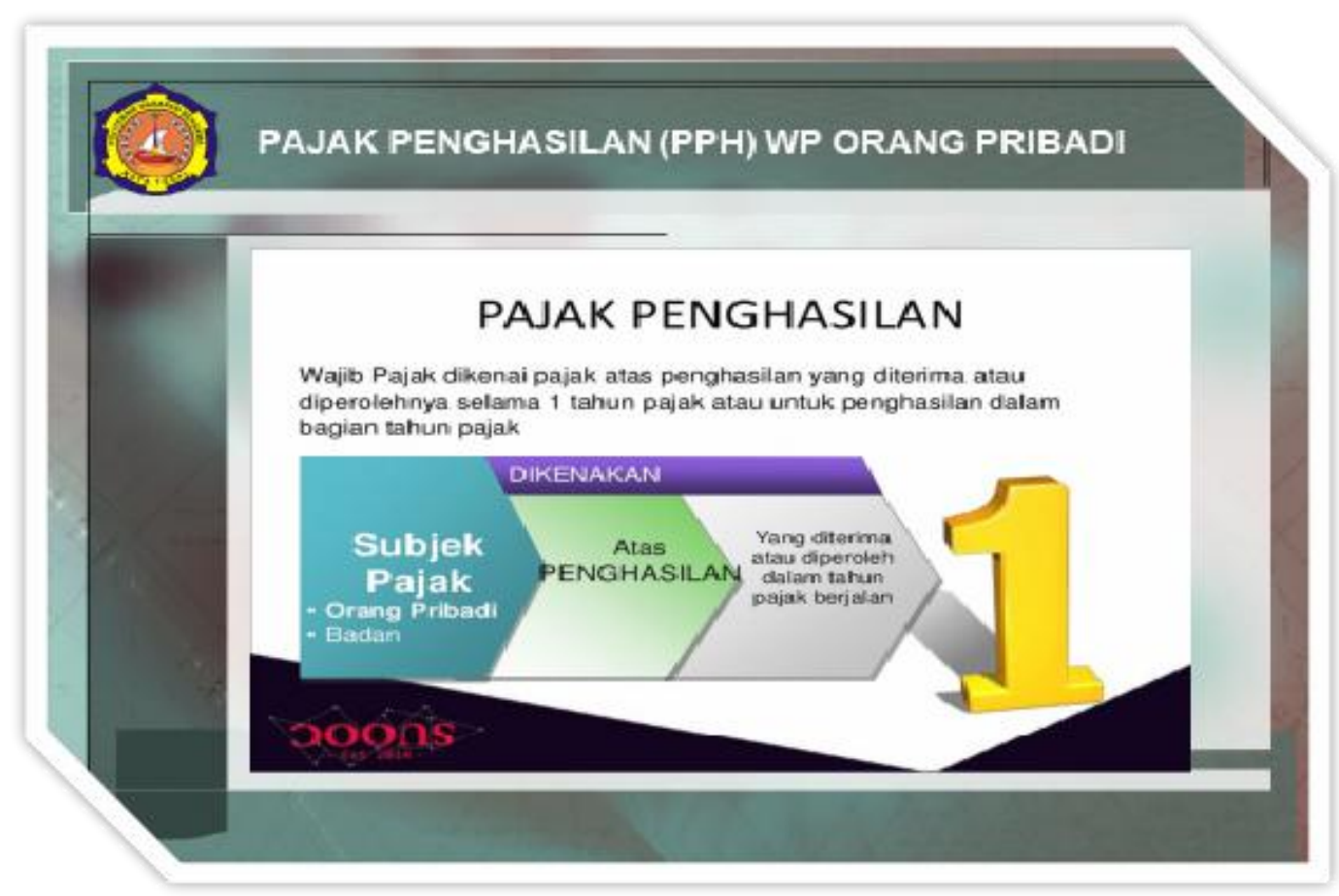

Gambar 3. Materi PPh WP Orang Pribadi 
3 Pengisian SPT Tahunan Orang Pribadi

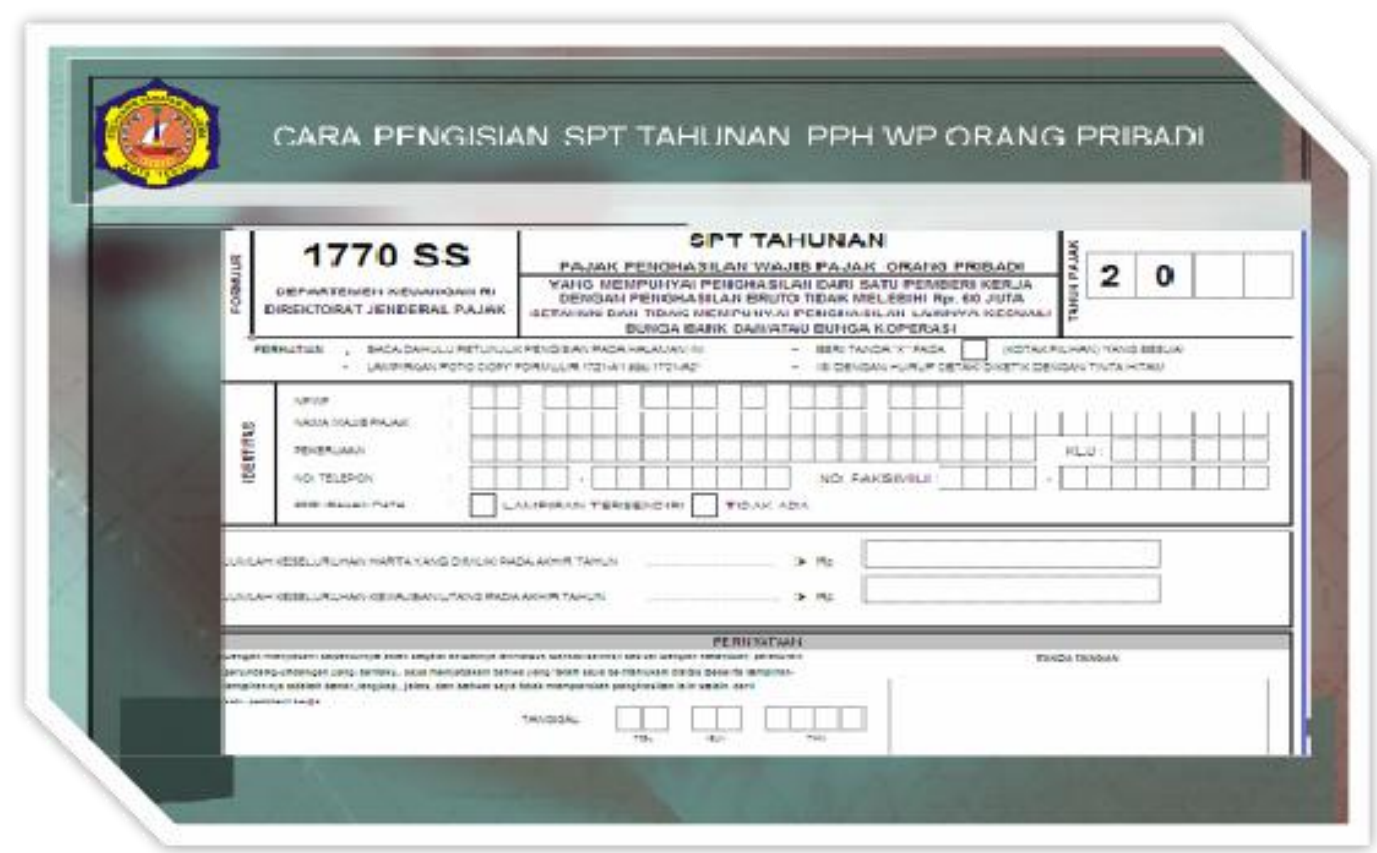

Gambar 4. Materi Cara Pengisian SPT Tahunan WP Orang Pribadi

4 Cara Penyampaian / Pelaporan SPT PPh Orang Pribadi

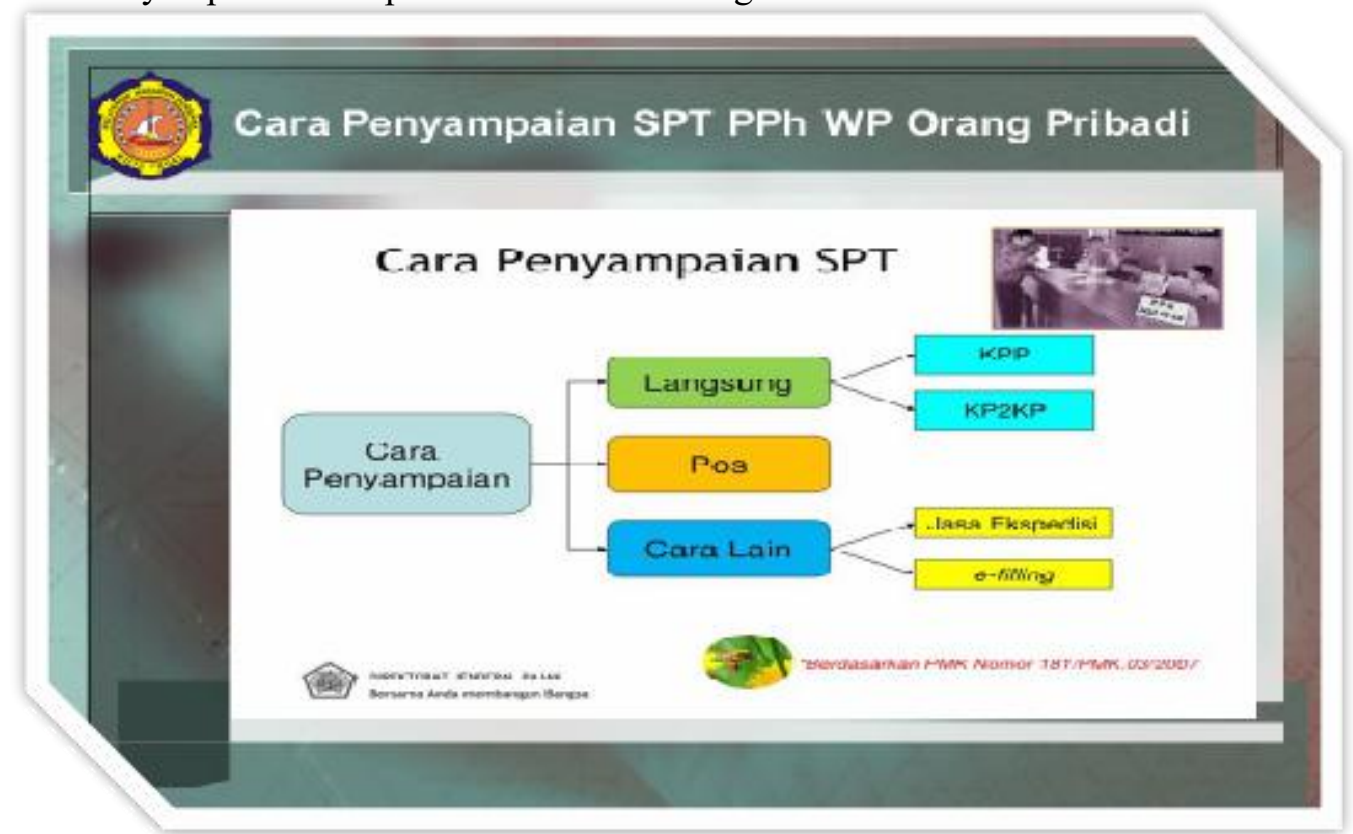

Gambar 5. Materi Cara Penyampaian SPT PPh WP Orang Pribadi 


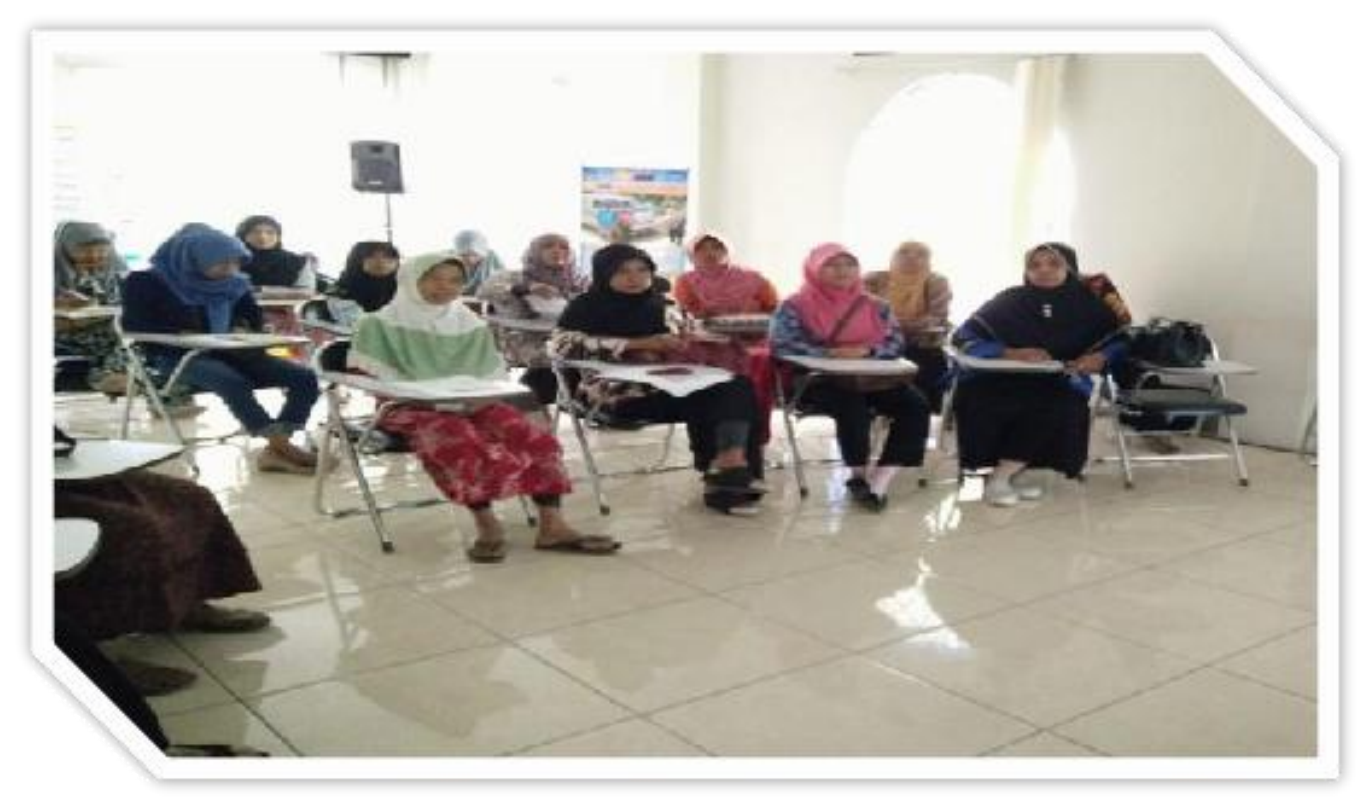

Gambar 6.Para Peserta mendengarkan materi yang diberikan oleh Nara Sumber.

Pada gambar 6 di atas memperlihatkan kegiatan pelatihan peningkatan pemahaman para pelaku Industri Kecil dan Menengah (IKM) tentang pentingnya pemahaman pajak bagi Industri Kecil dan Menengah (IKM) di Kota Tegal. Pada pemberian materi ini peserta menyimak tentang mengenai Pajak bagi Industri Kecil dan Menengah (IKM), PPh Orang Pribadi, Pengisian SPT Tahunan WP Orang Pribadi dan Cara melaporkan SPT PPh WP Orang Pribadi. Pada pelatihan ini juga disertai dengan tanya jawab dan diskusi dengan para peserta pelatihan.

\subsection{Capaian Kegiatan}

Kegiatan pengabdian pada masyarakat ini menghasilkan beberapa kegiatan yang dihasilkan diantaranya sebagai berikut (1) Terlaksananya kegiatan pelatihan perpajakan bagi para pelaku Industri Kecil dan Menengah (IKM) dan pengisian SPT $\mathrm{PPh}$ WP orang pribadi. (2) Terbentuknya forum untuk sharing dan konsultasi tentang pajak bagi para pelaku Industri Kecil dan Menengah (IKM) di Kota Tegal dengan Prodi D3 Akuntansi Politeknik Harapan Bersama.

\section{KESIMPULAN}

Pemahaman para pelaku Industri Kecil dan Menengah (IKM) di Kota Tegal tentang pentingnya pajak bagi Negara sangat dibutuhkan, agar para pelaku Industri Kecil dan Menengah (IKM) di Kota Tegal semakin banyak yang memahami tentang pajak khususnya SPT PPh orang pribadi. Para pelaku Industri Kecil dan Menengah (IKM) di Kota Tegal yang sudah menjadi wajib pajak harus tetap mengikuti perkembangan perpajakan dengan cara mengikuti pelatihan pengisian SPT pajak PPh orang pribadi agar para pelaku Industri Kecil dan Menengah (IKM) semakin mengerti akan pentingnya pemenuhan kewajiban perpajakan karena Undang-undang (UU) perpajakan di Indonesia terus mengalami perubahan dari waktu ke waktu. Perhitungan Pajak Penghasilan (PPh) baik wajib pajak Orang pribadi maupun wajib pajak badan mulai tahun 2009 harus mengacu pada Undang-Undang Pajak Penghasilan( PPh) yang baru.

\section{SARAN}

Kegiatan pengabdian masyarakat ini agar lebih ditingkatkan lagi, agar fungsi sivitas akademis tidak hanya menjadi menara gading, akan tetapi dapat memberikan sumbang sarannya untuk kebaikan dan kemajuan dalam mengembangkan usaha para pelaku Indusri Kecil dan Menengah (IKM) di Kota Tegal. Perlu diperluas lagi untuk peserta pelatihannya khususnya 
bagi para pelaku Indusri Kecil dan Menengah (IKM) tidak hanya masalah Pajak Orang Pribadi tetapi juga masalah Pajak Badan.

\section{UCAPAN TERIMA KASIH}

Terima kasih kepada Pusat Penelitian dan Pengabdian Masyarakat (P3M) Politeknik Harapan Bersama yang telah memberikan ijin dan pembiayaan sehingga kegiatan ini dapat terlaksana di tahun 2016.

\section{DAFTAR PUSTAKA}

[1] Mardiasmo. 2011. "Perpajakan Edisi Revisi”. Andi Publisher Yogyakarta.

[2] hhtp:// sim-ikm.tegalkota.go.id diakses tanggal 2 November 2017.

[3] Ratnasari, Kirwani. 2013. "Peranan Industri Kecil dan Menengah (IKM) dalam penyerapan Tenaga Kerja di Kabupaten Ponorogo". Diakses tanggal 3 November 2017.http://jurnalmahasiswa.unesa.ac.id/index.php/jupe/article/view/3625

[4] Willifia, Fifi Andika. 2013. “ Analisis Kesalahan Dalam Pengisian SPT Tahunan PPh Wajib Pajak Orang Pribadi Di Kantor Pelayanan Pajak Pratama Palembang Ilir Barat Tahun 2011”. Diakses tanggal 2 November 2017. http://eprints.mdp.ac.id/701/ 